\title{
Comparing Tree Heights among Montane Forest Blocks of Kenya Using LiDAR Data from GLAS
}

\author{
Mwangi James Kinyanjui,1,2, Ngugi John Kigomo33, Kamau Miriam Wambui ${ }^{1,4}$, \\ Nderitu Joel Kariuki1,4, Nyanjui Charles ${ }^{1,4}$, Nganga John Macharia ${ }^{1,4}$, \\ Ojijo William Odidi1,4, Ashiono Fredrick ${ }^{1,4}$, Owate Augustine Omamo ${ }^{1,4}$, \\ Ndirangu Monicah Katumbi1,4 \\ ${ }^{1}$ Department of Forestry, School of Natural Resources and Environmental Studies, Karatina University, \\ Karatina, Kenya \\ ${ }^{2}$ Department of Resource Surveys and Remote Sensing, Nairobi, Kenya \\ ${ }^{3}$ Kenya Forest Research Institute, Nairobi, Kenya \\ ${ }^{4}$ Kenya Forest Service, Nairobi, Kenya \\ Email: mwangikinyanjui@gmail.com
}

Received 24 December 2014; accepted 14 January 2015; published 23 January 2015

Copyright (C) 2015 by authors and Scientific Research Publishing Inc.

This work is licensed under the Creative Commons Attribution International License (CC BY).

http://creativecommons. org/licenses/by/4. 0/

(c) (i) Open Access

\section{Abstract}

This study was designed to use LiDAR data to research tree heights in montane forest blocks of Kenya. It uses a completely randomised block design to asses if differences exist in forest heights: 1) among montane forest blocks, 2) among Agro ecological zones (AEZ) within each forest block and 3) between similar AEZ in different forest blocks. Forest height data from the Geoscience Laser Altimeter System (GLAS) on the Ice Cloud and Land Elevation Satellite (ICESAT) for the period 2003-2009 was used for 2146 circular plots, of $0.2-0.25$ ha in size. Results indicate that, tree height is largely influenced by Agro ecological conditions and the wetter zones have taller trees in the upper, middle and lower highlands. In the upper highland zones of limited human activity, tree heights did not vary among forest blocks. Variations in height among forest blocks and within forest blocks were exaggerated in regions of active human intervention.

\section{Keywords}

Montane Forests, Tree Height, Agro Ecological Zones 


\section{Introduction}

Montane forests of Kenya otherwise referred to as water towers occur on mountainous regions that are water catchment areas (KWTA \& DRSRS, 2013). The forests have been referred to as mountain and range forests (Wass, 1995), moist and dry upland forests (Beentje, 1994) and Eastern Riftafromontane forests (White, 1983) due to their similarities in species composition and structure. Five montane blocks: Mau Forest complex, Mt Kenya, the Aberdares ranges, the Cherangany hills and Mt Elgon were noted as the major sources of water for the six drainage basins of Kenya (DRSRS \& KFWG, 2006) and these make up the biggest proportion of montane forests in Kenya.

Using the tropical flora of East Africa, Beentje (1994) defined possible species distribution areas within montane forests and these are strongly influenced by rainfall, soils and altitude which broadly translates to agro ecological factors (Jaetzold et al., 2007). The high rainfall areas occurring on the wind ward sides of mountains are characterised by a variety of broad leaved evergreen species while the dry montane forests found on the lee ward sides of mountains have a mixture of broadleaved and conifer species. Beentje (1994) further noted that altitudinal zonation profiles results to the mixed and conifer forests on the lower altitudes, while bamboo and moorland are found at higher altitudes.

Kinyanjui et al. (2014a) explained that variations occur in species dominance at various agro ecological zones in the Mau forest complex. Using species basal areas, they found out that the forests created flora zones or associations where a certain group of tree species dominated based on altitude, soils and climate. It was found that some tree species like Dombeya goetzenii (K. Schum), though not dominant at any of the species association zones, they were distributed over a wider ecological range indicating their adaptability to a variety of climate and altitude. Such species associations were found to affect the vertical and horizontal characteristics of forest structure which are largely species specific.

Apart from climate and altitude, human disturbance has been described as a major factor influencing species composition in forests of Kenya. Kinyanjui et al. (2013) explained that heavy encroachment including use of fires influenced the floristic charcterstics of some blocks of the Mau Forest Complex, affecting the regeneration of certain species and the overall recovery of the disturbed forest. The resultant species composition was influenced by species preferance, level of use and resilience of the forest to a specific disturbance.

Hitimana et al. (2009) attributed selective logging to the decline in the top canopy of Olea capensis (L) trees in Mt Elgon forest resulting to a general decrease in forest height. Similarly, Githae et al. (2007) noted that exploitation of firewood threatened Teclea nobilis (Delile) a top canopy species in Marsabit forest. Degradation activities like fires were found to reduce the health and density of forest vegetation and Kinyanjui (2011) stated that the heavily encroached East Mau forest block had inferior vegetation compared to other blocks of the Mau Forest Complex.

Kenya defines forests as those areas with a minimum of 15\% canopy closure, a minimum area of 0.5 ha and tree height above $2 \mathrm{~m}$ (KFS, 2013). Beyond this the forests have been categorised on the basis of canopy closure as dense (Canopy closure > 65\%), moderate (canopy closure 41\% - 65\%) and open (canopy closure 15\% - 40\%). The alteration of species composition in forests affects Kenya's definition of forests. For example, activities that eliminate tall trees or reduce the average height of the forest move the forest towards grassland. Such forest degradation activities including fires, selective removal and forest conversion into other uses, are common in forests of Kenya (Hitimana et al., 2009; Kinyanjui et al., 2013; Mullah et al., 2013).

\subsection{Forest Height as an Indicator of Forest Status}

Foresters have traditionally used tree height as an indicator of site productivity (Coops et al., 2011; Philip, 1994; Sturtevant et al., 2004). In addition Koch et al. (2004) explained that height growth in trees is dependent on environmental resources including soil, water and climate. The total of the biotic and abiotic interactions makes the mean height of trees differ among sites and, a forest in an area of more resources e.g. fertile soils would have taller trees and may stock more biomass (Culmsee et al., 2010). Therefore the theory of tree height growth potential has traditionally supported categorization of forests into site productivity indices but Coops et al. (2011) noted that height growth is species specific and can only be compared within a species.

Tree height is a common volume or biomass predictor variable and is only second in use to Diameter at breast height (Dbh) (Henry et al., 2011; Philip, 1994). Chave et al. (2005) explained that including tree height as a biomass predictor variable improved accuracy by at least $7 \%$. Due to the growing need to accurately estimate 
forest biomass, for purposes of REDD and greenhouse gas inventory (Sishir \& Stephan, 2012), methods of enhancing accuracy and ease in tree height measurement have been developed. Such methods include use of LiDAR technology that provides specific tree heights and associated terrain at specific points in a forest (Junttila et al., 2010).

\subsection{Using LiDAR to Measure Tree Heights}

Junttila et al. (2010) described Light Detection and Ranging (LiDAR) as a remote sensing technology that determines distances by taking the product of the speed of light and the time required for an emitted laser to travel to a target object. Such laser pulses are sent from a remotely placed sensor aboard a moving object like a satellite or an aircraft. Using algorithms that are based on the surface terrain, and the distance between the emitter and the forest canopy, the heights of different trees are calculated. Mitchard et al. (2012) explained that such LiDAR laser pulses can be used to categorise a forest into canopy classes such as top canopy, middle canopy and undergrowth and explain the density of each of such canopies.

The use of LiDAR technology allows assessment of tree heights in extensive and inaccessible forests (Wang et al., 2014). Noting that forest tree heights are difficult to measure using conventional forestry methods that are mainly based on triangulation, LiDAR tree height measurement offers a great opportunity for quick measurement of tree heights and allows large scale data provision (Chave et al., 2005). Such a method would complement ground inventories in Kenya's difficult forest conditions that oftenharbour dangerous wildlife (KFS, 2013). It may also allow quick comparisons of forest characteristics and aid in forest classification activities required for biomass mapping (Kinyanjui et al., 2014b).

\subsection{Use of Geoscience Laser Altimeter System (GLAS) Datasets}

A global dataset provided by the Geoscience Laser Altimeter System (GLAS) has widely been used to research tree heights in different forests of the world (Lefsky, 2010). The LiDAR data from the National Aeronautics and Space Administration (NASA) was taken by the Ice, Cloud, and land Elevation satellite (ICESat) in the period 2003-2009 and records forest tree heights using foot prints measuring 0.2 - 0.25 ha (Hilbert \& Schmullius, 2012). The data has been ground truthed in a variety of forest conditions of the world but (Wang et al., 2014) note that it requires refining to correct for topography.

Simard et al. (2011) used the GLAS data to map canopy heights across the globe while Mitchard et al. (2012) used the data to generate biomass maps in forests of Gabon. In Kenya, the green belt movement used GLAS data to generate a biomass map for Kenya using ground truthed points in Aberdares forest (TWHRC, 2007).

In Kenya, the LiDAR data provides tree height information for about 5500 foot prints in a variety of landuses. The data is ideal for mapping forest lands of Kenya whose definition partly relies on tree height (KFS, 2013). Though the collapse of the ICE-SAT at does not allow continued collection of tree data, the available data can be used to study our forests and identify causes of variations in tree characteristics. Such information is important for biomass mapping, species composition mapping and assessment of human effects in forests.

This study was designed to use LiDAR data to study tree heights of montane forest blocks of Kenya. Since montane forests are generalised as similar, factors that enhance similarities or cause dissimilarities may require a further analysis. The study objectives were therefore to assess if differences exist in forest heights 1) among montane forest blocks, 2) among Agro ecological zones (AEZ) within each forest block and 3) between similar AEZ in different forest blocks. The study is helpful in biomass inventory processes in forests of Kenya. It will guide on cases for generalisation in estimating biomass in montane forests of Kenya and determine drivers of change that affect forest heights.

\section{Methods}

\subsection{Overlay of LiDAR Data on Forest Maps}

Space-borne LiDAR data from the Geoscience Laser Altimeter System (GLAS) on the Ice Cloud and Land Elevation Satellite (Ice-SAT) for the period from 2003-2009 was downloaded from the NASA Distributed Active Archive Center (DAAC) at the National Snow and Ice Data Center (NSIDC) website (http://nsidc.org/daac) and clipped based on the boundaries of the gazetted forests of Kenya. The data was further categorised into the various agro ecological zones of each montane forest block. The data was then refined to cover only areas of 
natural forests based on forest maps of 2000 and 2010 (KFS, 2013). There were a total of 2146 data points distributed as 365 in Aberdare forest, 93 in Cherangany forest, 1129 in Mau forest, 186 in Mt Elgon and 373 in Mt Kenya (Figure 1).

\subsection{Data Analysis}

Data for agro ecological zones (AEZ) (Jaetzold et al., 2007) was collated and clipped for each of the Agro ecological zones for each water tower. The Agro ecological zones are based on climate and altitude and are indications of the expected land productivity. The represented AEZ are summarised in Table 1 . The collated data was subjected to a one way ANOVA tests to identify if differences in forest height exist among forest blocks. ANOVA was also done to test differences among AEZ within a water tower and among AEZ in the different water towers. Tukey's multiple comparison tests (Zar, 2010) were done to identify specific variations among water towers and among AEZ. Factors that cause differences in tree height in the various categories tested were investigated using existing ground forest information.

\section{Results}

\subsection{Height Variations among Water Towers}

The tree heights varied significantly $(P<0.05)$ among the forests of the water towers. The average heights were

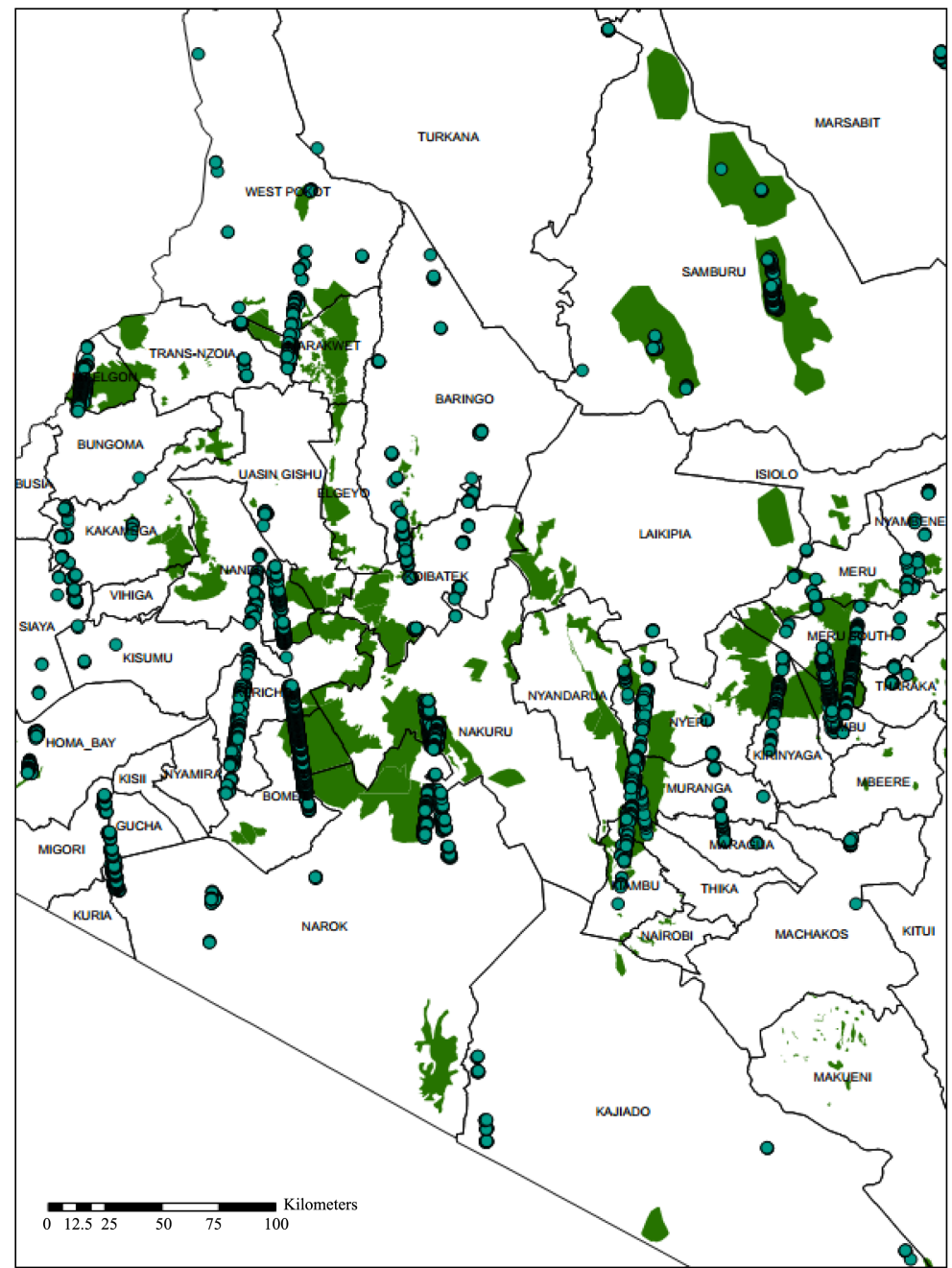

Figure 1. Distribution of the height data points in different forest blocks of Kenya. 
$18.66 \mathrm{~m}$ in Mt Elgon forest block (SEE = 0.48), $17.45 \mathrm{~m}$ in Mt Kenya forest block (SEE = 0.44), $16.36 \mathrm{~m}$ in Cherangany Hills forest block (SEE $=0.52$ ), 14.68 in Aberdare ranges forest block (SEE $=0.58$ ) and 13.74 in the Mau forest complex (SEE $=0.20$ ). Tukey's multiple comparison test (Table 2) indicated that forest heights differed among most of the montane forests. It was only in the cases of Mt Kenya versus Cherangany hills and Aberdare versus Mau forest where forest heights did not differ. In some cases the differences in height were quite significant as illustrated by the high q value in Mt Elgon vs Mau and also Mt Kenya vs Mau. The results classify the montane forests of Kenya into two extremes in terms of forest heights. On the lower scale are Aberdares and Mau forest complex while on the upper scale, there is Mt Elgon and Mt Kenya forests.

A graphical presentation of the forest vertical structure (Figure 2) showed that in Mt Kenya and the Aberdares, have forest heights of up to $60 \mathrm{~m}$ while in Mau, Mt Elgon and Cherangany, the tallest forests reached 40m. The vertical structure also illustrated that in Mt Elgon, the average height of the trees was higher than in the other forests. The Mau forest, which had the biggest number of data points, there was a uniform distribution of trees from the small sizes and climaxes at about $30 \mathrm{~m}$ height.

The results of tree height may be an illustration of the existing conditions in the forests with Mau forest having been rated as degraded (Kinyanjui et al., 2013; Mullah et al., 2013) and having the lowest basal areas among the forests of Kenya (Wass, 1995). However, the Mau forest might also be the best indicator of forest conditions

Table 1. Characteristics of the agro ecological zones of Kenya (Jaetzold et al., 2007).

\begin{tabular}{|c|c|}
\hline AEZ & Characteristics of AEZ \\
\hline LH0 & Per humid, Lower Highland: Ever wet, Annual mean temperature, $10^{\circ} \mathrm{C}-15^{\circ} \mathrm{C}$, occasional night frost \\
\hline LH1 & $\begin{array}{l}\text { Humid, Lower Highland: Length of growing period greater than } 270 \text { days. Evergreen, } \\
\text { Annual mean temperature } 15^{\circ} \mathrm{C}-18^{\circ} \mathrm{C} \text {, Monthly minimum } 8^{\circ} \mathrm{C}-11^{\circ} \mathrm{C} \text {, no frost }\end{array}$ \\
\hline LH2 & $\begin{array}{l}\text { Sub-humid, Lower Highland: Length of growing period is } 180-270 \text { days. One or two dry months. } \\
\text { Annual mean temperature, } 15^{\circ} \mathrm{C}-18^{\circ} \mathrm{C} \text { Monthly minimum } 8^{\circ} \mathrm{C}-11^{\circ} \mathrm{C} \text {, no frost }\end{array}$ \\
\hline LH3 & $\begin{array}{l}\text { Semi-humid, Lower Highland: Three to five dry months, Annual mean temperature, } \\
\qquad 15^{\circ} \mathrm{C}-18^{\circ} \mathrm{C} \text {, Monthly minimum } 8^{\circ} \mathrm{C}-11^{\circ} \mathrm{C} \text {, no frost }\end{array}$ \\
\hline $\mathrm{UHO}$ & Per humid, Upper Highland: Ever wet, Annual mean temperature, $10^{\circ} \mathrm{C}-15^{\circ} \mathrm{C}$, occasional night frost \\
\hline UH1 & $\begin{array}{l}\text { Humid, Upper Highland: Length of growing period greater than } 270 \text { days. Evergreen. } \\
\text { Annual mean temperature, } 10^{\circ} \mathrm{C}-15^{\circ} \mathrm{C} \text {, occasional night frost }\end{array}$ \\
\hline UH2 & $\begin{array}{l}\text { Sub-humid, Upper Highland: Length of growing period is } 180-270 \text { days. One or two dry months., } \\
\text { Annual mean temperature, } 10^{\circ} \mathrm{C}-15^{\circ} \mathrm{C} \text {, occasional night frost }\end{array}$ \\
\hline UM1 & $\begin{array}{l}\text { Humid, Upper midland: Length of growing period greater than } 270 \text { days, } \\
\text { Annual mean temperature, } 18 \text { - } 21 \text { degrees, Monthly minimum } 11 \text { - } 14\end{array}$ \\
\hline
\end{tabular}

Table 2. Tukey’s multiple comparison test results showing differences among forests.

\begin{tabular}{|c|c|c|c|c|c|}
\hline Comparisons & $\begin{array}{c}\text { Difference } \\
\text { in mean }\end{array}$ & SE & $\mathbf{Q}$ & Tabulated $q_{0.05}$ & Conclusion \\
\hline Mt Elgon vs Mt Kenya & 1.21 & 0.43 & 2.83 & $<2.77$ & Heights differ \\
\hline Mt Elgon vs Cherangany & 2.30 & 0.58 & 3.95 & $<2.77$ & Heights differ \\
\hline Mt Elgon vs Aberdare & 3.98 & 0.48 & 8.26 & $<2.77$ & Heights differ \\
\hline Mt Elgon vs Mau & 4.92 & 0.37 & 13.14 & $<2.77$ & Heights differ \\
\hline Mt Kenya vs Cherangany & 1.09 & 0.54 & 2.00 & $<2.77$ & Heights do not differ \\
\hline Mt Kenya vs Aberdare & 2.77 & 0.43 & 6.38 & $<2.77$ & Heights differ \\
\hline Mt Kenya vs Mau & 3.71 & 0.31 & 11.95 & $<2.77$ & Heights differ \\
\hline Cherangany vs Aberdare & 1.68 & 0.59 & 2.86 & $<2.77$ & Heights differ \\
\hline Cherangany vs Mau & 2.62 & 0.50 & 5.21 & $<2.77$ & Heights differ \\
\hline Aberdare vs Mau & 0.94 & 0.38 & 2.46 & $<2.77$ & Heights do not differ \\
\hline
\end{tabular}


because the data captured the biggest number of sample points and they were distributed among a variety of ecological conditions.

The taller trees in Mt Elgon illustrate its close association and its characteristics of nearby tropical lowland forest types like Kakamega forest which is the only forest in Kenya with characteristics typical of the GuineoCongolean vegetation (Glenday, 2006). The low tree height in Aberdares forest may be associated to the fact that some sample points fell in regions of bamboo forest-mixture and Kinyanjui et al. (2011) noted that bamboo vegetation comprises the largest vegetation type in the forest (Figure 3).

\subsection{Height Variations among AEZ}

An investigation into the specific AEZ with pooled data from all the montane forests showed that tree heights varied significantly among AEZ. The average heights reduced with a decrease in wetness in the upper highland zones resulting to $16.14 \mathrm{~m}$ in UH0, $15.18 \mathrm{~m}$ in UH1 and $14.31 \mathrm{~m}$ in UH2. However in the lower highland zones, LH0 had an average of $17.58 \mathrm{~m}$ and LH1 had $19.28 \mathrm{~m}$ showing that wetter lower highlands had taller trees. The averages for the LH2 and LH3 were quite lower with values of $5.41 \mathrm{~m}$ and $4.16 \mathrm{~m}$ respectively, illustrating that trees are normally shorter in the drier areas. However it was only in the Mau forest that data points fell on the LH2 and LH3.

Within the UH0, ANOVA showed significant variations in tree heights $(P<0.05)$ in forests of Aberdares, Mt Elgon and Mt Kenya. The difference was attributed to the taller trees in Mt Elgon which had an average height of $19.03 \mathrm{~m}$ as compared to Aberdare with $14.30 \mathrm{~m}$. There were also variations in tree height in the LH1 represented by Mau, Mt Kenya and Mt Elgon. The variations were attributed to the lower tree heights in Mau forests which had an average of $17 \mathrm{~m}$ as compared to $20 \mathrm{~m}$ in the other two water towers. Similarly tree height varied within the UH2 where Mau, Cherangany and Aberdare were represented. Here the Cherangany forest had significantly taller trees at $17 \mathrm{~m}$ in average compared to $12.6 \mathrm{~m}$ and $13.0 \mathrm{~m}$ in Mau and Aberdares respectively.

It was only in the UH1 which had sample points in all the water towers, that ANOVA $(P<0.05)$ gave no significant variation in tree heights. The average tree heights in UH1 were $15.64 \mathrm{~m}$ in Aberdares, $15.39 \mathrm{~m}$ in Cherangany, $12.88 \mathrm{~m}$ in Mau, 15.49 in Mt Elgon and $16.51 \mathrm{~m}$ in Mt Kenya. In this upper highland humid zone with a growing period of more than 270 days and anannual mean temperature of $10^{\circ} \mathrm{C}-15^{\circ} \mathrm{C}$ (Jaetzold et al., 2007), species composition was described by Beentje (1994) as largely comprising of mixed broadleaved and coniferous trees including Podocarpus latifolius (Thunb. Mirb, Juniperus procera (Endl) and Olea europaea ssp. africana in the drier areas and Dombeya goetzenii (K. Schum), Tabernaemontana stapfiana (Britten) and Dracaena afromontana (Mildbr) in the wetter areas.

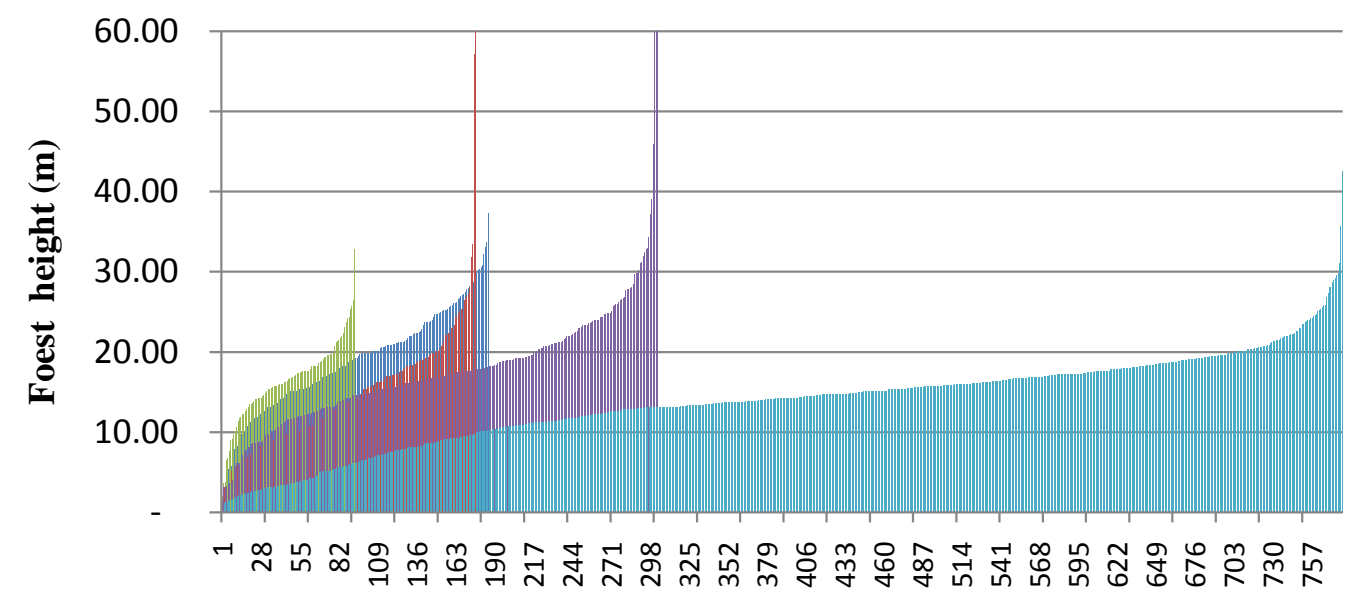

LiDAR Data Points

$\square$ Mt elgon $\quad$ Aberdare $\square$ Cherangany $\quad$ Mt kenya $\square$ Mau

Figure 2. Graphical representation of distribution of trees among heights in the water towers. 
Being in the upper highland zone, the forests are relatively undisturbed because human influence reduces with distance from the farms (Hitimana et al., 2009; Kinyanjui et al., 2014b) and this result could be an indicator of the forest heights in the montane forests of Kenya in their natural conditions. The lack of variation in tree height among the water towers in these undisturbed zones is a strong justification for characterising the forests as similar. It also proposes that mean variations in tree heights among montane forests could be attributed to human influence (Figure 4).

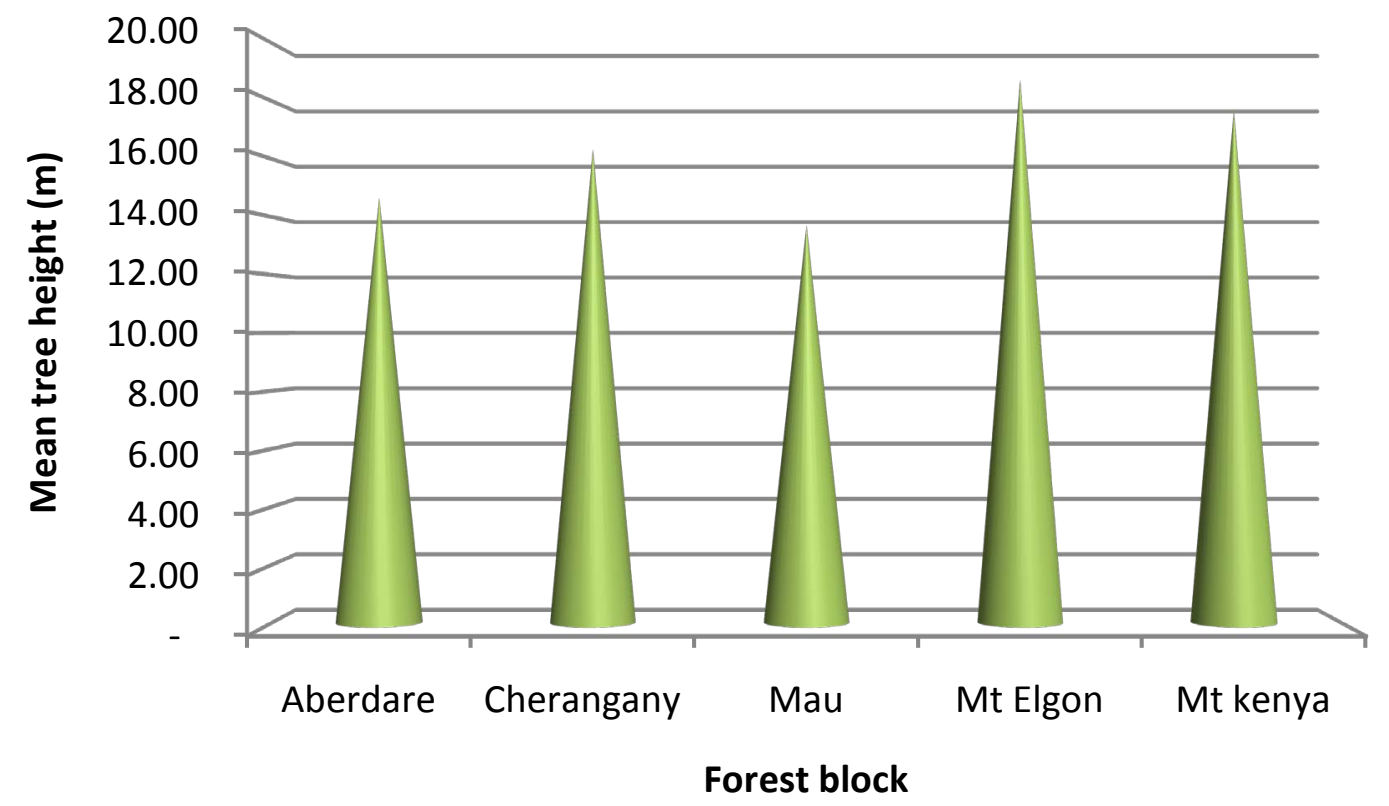

Figure 3. A comparison of tree heights among water towers.

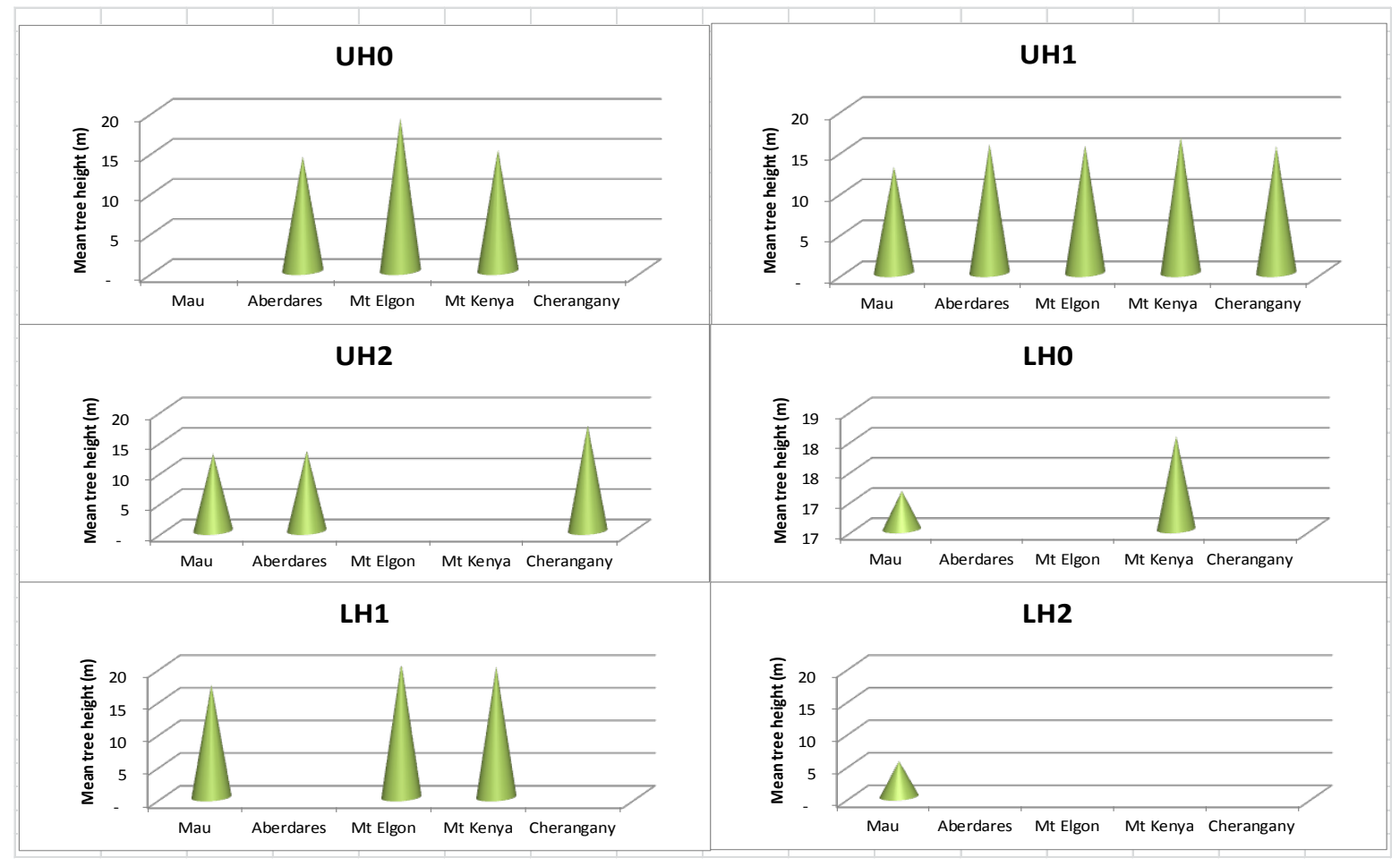

Figure 4. A comparison of forest heights among AEZ in the water towers. 


\subsection{Height Variations within Water Towers}

Four water towers: Aberdares, Mau, Mt Elgon and Mt. Kenya, had data points distributed in a variety of AEZ. In Mau forest where data points were distributed among six AEZ, tree heights were categorised into three groups. The UH0 and LH1 had relatively taller trees with means of $17.13 \mathrm{~m}$ and $17.23 \mathrm{~m}$ respectively. The UH1 and UH2 had moderate heights of $12.88 \mathrm{~m}$ and $12.62 \mathrm{~m}$ respectively while on the lower side the LH2 and LH3 had significantly shorter trees with means of $5.41 \mathrm{~m}$ and $4.16 \mathrm{~m}$ respectively In the Mau forest, tree heights can clearly be attributed to AEZ with wetter and warmer climates having taller trees while drier climates have shorter trees. The results do not indicate effects of human degradation on tree heights and this may illustrate the ability of the higher potential zones to regenerate and retain typical forest heights.

In Mt Elgon, height variation was due to the tall trees in the LH1 averaging $20.59 \mathrm{~m}$ and the short trees in the UM1 averaging $8.26 \mathrm{~m}$. This is a clear illustration of effects of human degradation on forest heights since the UM1 was noted to be experiencing degradation. Conversely in Mt Kenya, it was UM1 that caused variation, with extremely tall trees averaging $26.16 \mathrm{~m}$ as compared to $18.04 \mathrm{~m}$ in the LH0, $20.02 \mathrm{~m}$ in the LH1, $15.09 \mathrm{~m}$ in the UH0 and $16.51 \mathrm{~m}$ in the UH1. The tall trees in the UM1 were from 10 data points and comprised a Eucalyptus crop growing in the natural forest. The case of Mt Kenya is a good illustration of the effects of exotic trees on a forest which may influence stocking densities. In the Aberdares forest, significant variation in tree heights occurred among the AEZ; UH0, UH1 and UH2 with average tree heights of $14.30 \mathrm{~m}, 15.64 \mathrm{~m}$ and $13.12 \mathrm{~m}$ respectively.

\section{Conclusion}

Forest height results in the montane forests indicate that, tree growth is largely influenced by Agro ecological conditions of climate and altitude. However influence of human activity may be identified as in the case of AEZ, UM1 in Mt Kenya where exotic trees have been introduced in the natural forest. The case is also evident in AEZ LH2 and LH3 in Mau forest which had very short trees. Though falling within Kenya's definition of forests (KFS, 2013), the short trees with averages of $5.41 \mathrm{~m}$ and $4.16 \mathrm{~m}$ in the Eastern and Kilombe blocks of the Mau forest were due to a combination of climatic factors and effects of human degradation.

Generally, upper highland forests had tall trees and the variations among water towers and within water towers were not exaggerated. This could be attributed to the lesser effects of human activities in these forest located far from human settlements. This may justify that variations in tree height among water towers are largely influenced by human effects.

The study has demonstrated application of LiDAR technology in extensive forest inventory in Kenya. Integrating LiDAR technology within the proposed national forest inventory will not only improve the accuracy of the output but also reduce the cost and time required to collect forest information. The failure of the ICEsat means that the accuracy of the tree height data referred here may never be ascertained. However, the on-going forest inventory programme in Kenya benefits from the findings of this research in noting sources of variations in tree characteristics and in developing a forest sampling scheme. The study proposes a clear ground truthing scheme for to calibrate LiDAR derived data and if possible use the available GLAS data to scale up the national data set for tree heights.

\section{Acknowledgements}

This study would not have been possible without the availability of data from NASA Distributed Active Archive Center (DAAC) at the National Snow and Ice Data Center (NSIDC). We also appreciate the guidance of Silva Carbon and Building Carbon Bridges project who introduced us to the GLAS data.

\section{References}

Beentje, H. J. (1994). Kenya Trees, Shrubs and Lianas. National Museums of Kenya, Nairobi.

Chave, J., Andalo, C., Brown, S., Cairns, M. A., Chambers, J. Q., Eamus, D., Fölster, H., Fromard, F., Higuchi, N., Kira, T., Lescure, J.-P., Nelson, B., Ogawa, H., Puig, H., Riéra, B. N., \& Yamakura, T. (2005). Tree Allometry and Improved Estimation of Carbon Stocks and Balance in Tropical Forests. Oecologia, 145, 87-99.

Coops, N. C., Gaulton, R., \& Waring, R. H. (2011). Mapping Site Indices for Five Pacific Northwest Conifers Using a Physiologically Based Model. Applied Vegetation Science, 14, 268-276.

Culmsee, H., Leuschner, C., Moser, G., \& Pitopang, R. (2010). Forest Aboveground Biomass along an Elevational Transect 
in Sulawesi, Indonesia, and the Role of Fagaceae in Tropical Montane Rain Forests. Journal of Biogeography, 37, 960974. http://dx.doi.org/10.1111/j.1365-2699.2009.02269.x

DRSRS (Department of Resource Surveys and Remote Sensing) and KFWG (Kenya Forests Working Group) (2006). Changes in Forest Cover in Kenya’s Five Water Towers. 2003-2005. East African Wildlife Society. http://www.unep.org/dewa/Portals/67/pdf/forest_catchment_2005_report.pdf

Githae, E. W., Chuah-Petiot, M., Mworia, J. K., \& Odee, D. W. (2007). A Botanical Inventory and Diversity Assessment of Mt. Marsabit Forest, a Sub-Humid Montane Forest in the Arid Lands of Northern Kenya. African Journal of Ecology, 46, 39-45.

Glenday, J. (2006). Carbon Storage and Emissions Offset Potential in an East African Tropical Rainforest. Forest Ecology and Management, 235, 72-83.

Henry, M., Picard, N., Trotta, C., Manlay, R. J., Valentini, R., Bernoux, M., \& Saint-André, L. (2011). Estimating Tree Biomass of Sub-Saharan African Forests: A Review of Available Allometric Equations. Silva Fennica, 45, 477-569.

Hilbert, C., \& Schmullius, C. (2012). Influence of Surface Topography on ICESat/GLAS Forest Height Estimation and Waveform Shape. Remote Sensing, 4, 2210-2235. http://dx.doi.org/10.3390/rs4082210

Hitimana, J., Kiyiapi, J. L., Njunge, J. T., \& Bargerei, R. (2009). Disturbance Indicators and Population Decline of Logged Species in Mt. Elgon Forest, Kenya. African Journal of Ecology, 48, 699-708.

Jaetzold, R., Schmidt, H., Hornet, Z. B., \& Shisanya, C. A. (2007). Farm Management Handbook of Kenya. Vol. 11/C of Natural Conditions and Farm Information (2nd ed.). Nairobi: Ministry of Agriculture/GTZ.

Junttila, V., Kauranne, T., \& Leppänen, V. (2010). Estimation of Forest Stand Parameters from Airborne Laser Scanning Using Calibrated Plot Databases. Forest Science, 56, 257-270.

KFS (2013). National Forest Resource Mapping and Capacity Development for the Republic of Kenya. Forest Preservation Programme, Report No. KEF09/11494/01. Nairobi: Kenya Forest Service.

Kinyanjui, M. J. (2011). NDVI Based Vegetation Monitoring in the Mau Forest Complex, Kenya. African Journal of Ecology, 49, 165-174. http://dx.doi.org/10.1111/j.1365-2028.2010.01251.x

Kinyanjui, M. J., Karachi, M., \& Nyabuti, K. N. (2013). Natural Regeneration and Ecological Recovery in Mau Forest Complex, Kenya. Open Journal of Ecology, 3, 417-422. http://dx.doi.org/10.4236/oje.2013.36047

Kinyanjui, M. J., Latva-Käyrä, P., Bhuwneshwar, P. S., Kariuki, P., Gichu, A., \& Wamichwe, K. (2014b). An Inventory of the Above Ground Biomass in the Mau Forest Ecosystem, Kenya. Open Journal of Ecology, 4, 619-627. http://dx.doi.org/10.4236/oje.2014.410052

Kinyanjui, M. J., Mutwiri, F., Ojwala, A. M., \& Ibrahim, S. (2011). Mapping the Status of Aberdare Water Tower. Technical Report No 192, Nairobi: Department of Resource Surveys and Remote Sensing.

Kinyanjui, M. J., Shisanya, C. A., Ondimu, K. N., Wargute, P. W., \& Ojwala, M. A. (2014a). Assessing Tree Species Dominance along an Agro Ecological Gradient in the Mau Forest Complex, Kenya. Open Journal of Ecology, 4, 662-670. http://dx.doi.org/10.4236/oje.2014.411056

Koch, G. W., Sillett, S. C., Jennings, G. M., \& Davis, S. D. (2004). The Limits to Tree Height. Nature, 428, 851-854. http://dx.doi.org/10.1038/nature02417

KWTA (Kenya Water Towers Agency), \& DRSRS (Department of Resource Surveys and Remote Sensing) (2013). Rapid Assessment of the Mau Water Tower. Government Press.

Lefsky, M. A. (2010). A Global Forest Canopy Height Map from the Moderate Resolution Imaging Spectroradiometer and the Geoscience Laser Altimeter System. Geophysical Research Letters, 37, Article ID: L15401. http://dx.doi.org/10.1029/2010GL043622

Mitchard, E. T. A., Saatchi, S. S., White, L. J. T., Abernethy, K. A., Jeffery, K. J., Lewis, S. L., Collins, M., Lefsky, M. A., Leal, M. E., Woodhouse, I. H., \& Meir1, P. (2012). Mapping Tropical Forest Biomass with Radar and Spaceborne LiDAR in Lopé National Park, Gabon: Overcoming Problems of High Biomass and Persistent Cloud. Biogeosciences, 9, $179-191$. http://dx.doi.org/10.5194/bg-9-179-2012

Mullah, C. J. A., Klanderud, K., Totland, Ø., \& Kigomo, B. (2013) Relationships between the Density of Two Potential Restoration Tree Species and Plant Species Abundance and Richness in a Degraded Afromontane Forest of Kenya. African Journal of Ecology, 52, 77-87. http://dx.doi.org/10.1111/aje.12095

Philip, M. S. (1994). Measuring Trees and Forests (2nd ed.). Aberdeen: Aberdeen University Press.

Simard, M., Pinto, N., Fisher, J. B., \& Baccini, A. (2011). Mapping Forest Canopy Height Globally with Spacebornelidar. Journal of Geophysical Research, 116, Article ID: G04021. http://dx.doi.org/10.1029/2011JG001708

Sishir, G., \& Stephan, A. P. (2012). Carbon Pools of an Intact Forest in Gabon. African Journal of Ecology, 50, 414-427. http://dx.doi.org/10.1111/j.1365-2028.2012.01337. x

Sturtevant, B. R., \& Seagle, S. W. (2004). Comparing Estimates of Forest Site Quality in Old Second-Growth Oak Forests. 
Forest Ecology \& Management, 191, 311-328. http://dx.doi.org/10.1016/j.foreco.2003.12.009

TWHRC (2007). Kenya: Aboveground Live Woody Biomass 2007. The Woods Hole Research Centre. http://www.whrc.org/education/rwanda/pdf/Kenya_Biomass_Map.pdf

Wang, X. Y., Huang, H. B., Gong, P., Liu, C. X., Li, C. C., \& Li, W. Y. (2014). Forest Canopy Height Extraction in Rugged Areas with ICESat/GLAS Data. IEEE Transactions on Geoscience and Remote Sensing, 52.

Wass, P. (Ed.) (1995). Kenya's Indigenous Forests: Status, Management and Conservation. Gland, Switzerland \& Cambridge, UK: IUCN, 205 p.

White, F. (1983). The Vegetation of Africa: A Descriptive Memoir to Accompany the UNESCO/AETFAT/UNSO Vegetation Map of Africa. Paris: UNESCO.

Zar, J. H. (2010). Biostatistical Analysis (5th ed.). Englewood Cliffs, NJ: Prentice-Hall, 944.

\section{Abbreviations}

AEZ: Agro Ecological Zones

DAAC: Distributed Active Archive Center

DRSRS: Department of Resource surveys and Remote Sensing

GLAS: Geoscience Laser Altimeter System

KFS: Kenya Forest Service

KFWG: Kenya Forest Working Group

KWTA: Kenya Water Towers Agency

LH: Lower Highland

LiDAR: Light Detection and Ranging

NASA: National Aeronautics and Space Administration

NSIDC: National Snow and Ice Data Center

TWHRC: The Woods Hole Research Centre

UH: Upper Highland

UM: Upper Midland 
Scientific Research Publishing (SCIRP) is one of the largest Open Access journal publishers. It is currently publishing more than 200 open access, online, peer-reviewed journals covering a wide range of academic disciplines. SCIRP serves the worldwide academic communities and contributes to the progress and application of science with its publication.

Other selected journals from SCIRP are listed as below. Submit your manuscript to us via either submit@scirp.org or Online Submission Portal.
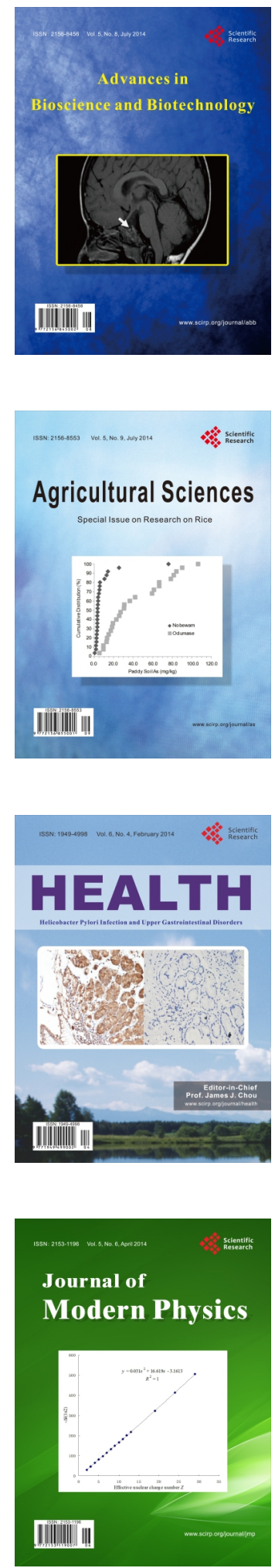
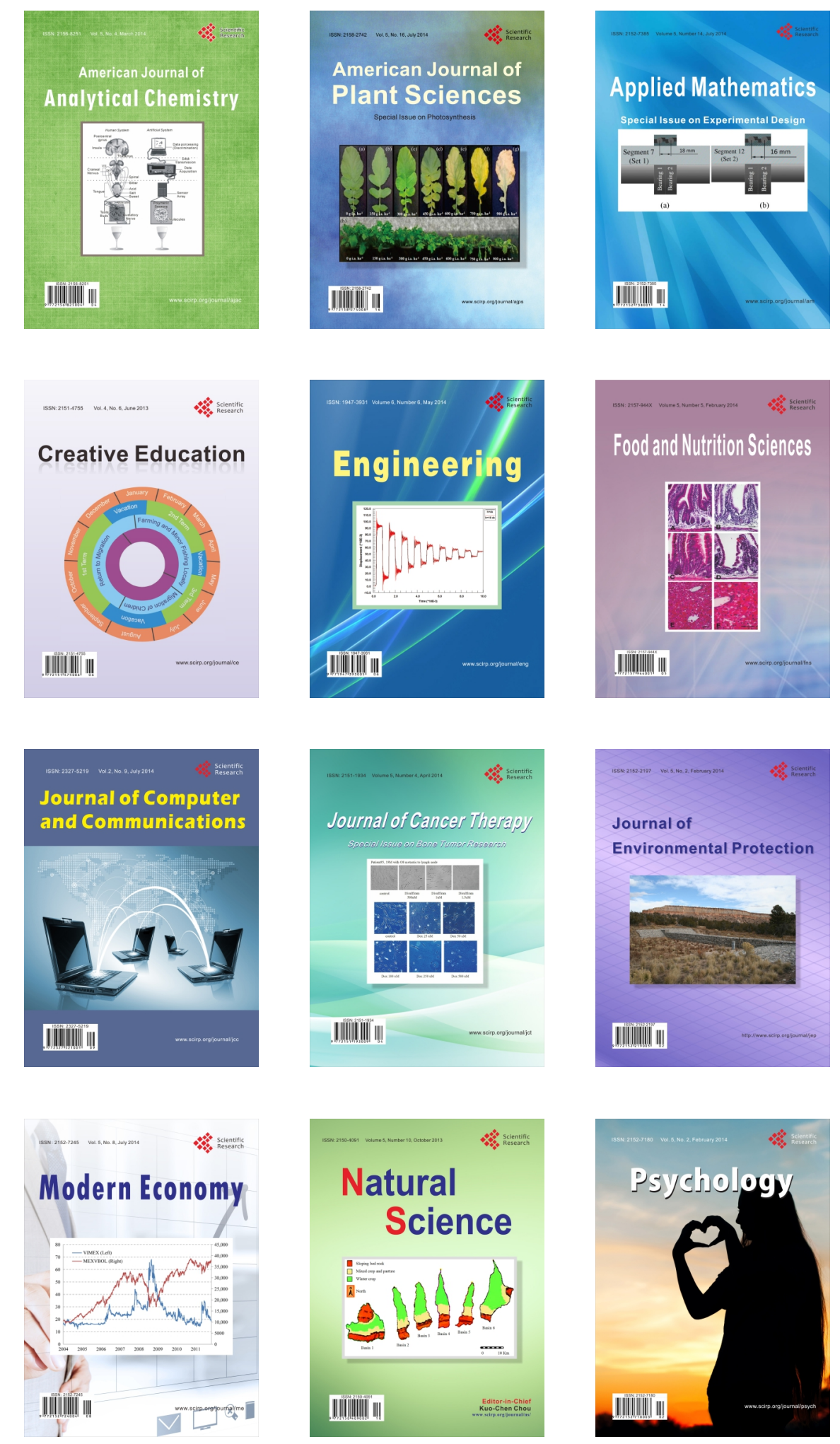